\section{Gulbenkian Institute flourishes}

SIR-Your supplement on "Science in Iberia" (Nature 324, 313-332; 1986) aptly describes the role of the Calouste Gulbenkian Foundation in the growth of scientific activities in Portugal. But one dis turbing half-truth found its way into your text where you refer (p. 332) to the Gulbenkian Institute of Science. Although it is true that the foundation has closed down all activities in the Gulbenkian Institute of Science in areas other than biology, the institute's activities in biology are flourishing and being strengthened. The foundation has recognized that biotechnology cannot be significantly developed in Portugal without a strong research sector in basic biology. Thus, while government agencies are planning, as you correctly report, to establish an institute of biotechnology, the foundation sees an increasing need to maintain in full activity its Gulbenkian Institute of Science with respect to basic research and graduate teaching in microbiology, virology, cytogenetics and molecular genetics as well as continuing its financial support of research in other Portugese intitutions and the financing of Portuguese scientists studying abroad.

Joel SERrão

Horácio MEnano

J. DAVID-FERREIRA N. VAN UDEN

Gulbenkian Institute of Science,

Rua da Quinta Grande, Apt 14,

2781 Oeiras Codex, Portugal

\section{Antarctic research}

Sir-The statements made by Francis Auburn in his recent review of two books about Antarctic (Nature 323, 22; 1986) were disconcerting to us as Antarctic scientists. We do not, of course, represent the official US government stance on the continent, but as scientists who are involved in research activities and who recently returned from a research trip there (1985-86 field season), we feel that several of Auburn's comments deserve challenge.

The National Science Foundation (NSF, which administers the US Antarctic Research Program) makes a consistent and detailed effort to educate each scientist planning to conduct a research programme in Antarctica to both the letter and the spirit of the treaty, and our interactions with researchers and support staff there indicate that most are well aware of the unique environmental and political situation in Antarctica. Most are pleased that the establishment of the treaty has allowed them to conduct exciting and unique research in this remote area. Auburn asks what NSF is trying to do in Antarctica and mentions that its continued support of basic research should be criticized. Why? The principal thrust of the treaty was to set aside national claims and differences in order to encourage basic scientific research in and around Antarctica. He asks why, for example, the United States should support krill research when there are apparently no plans for large-scale US exploitation of this resource. But this is the nature of basic research.

In order to conduct research in the US Antarctic programme, scientists must submit proposals to NSF. Such proposals are then judged on their scientific merit, including what basic knowledge they will contribute to the field and what scientific questions they will attempt to answer. These proposals are peer-reviewed. Myopically, Auburn views this type of research as a "gift to Soviet krill exploitation", but we as scientists see basic research as a gift to all of mankind, especially future generations. From the limited perspective of today, the potential "economic" value of basic research may take decades to be realized. We believe that it is to the credit of NSF and similar organizations in other countries that they support basic research in such a remote, unique and exciting area as Antarctica. It is indeed the last frontier on this planet, and perhaps the scientific progress made possible by the treaty will serve as a catalyst in demonstrating the benefits from international cooperation.

Department of Biology,

Hope College,

Holland, Michigan 49423, USA

Department of Botany,

THOMAS N. TAYLOR

Ohio State University,

Columbus, Ohio 43210, USA

\section{Sexist advertising}

SIR-For nearly a year, Nature has intermittently published on the back cover an advertisement in which a woman is used in a sexually exploitive fashion (for example, the issue of 13-19 November 1986). I resent this distasteful practice and have written to you previously. Why cannot such an otherwise enlightened journal cease publishing sexist ads?

\section{Worcester Foundation}

Thoru Pederson

for Experimental Biology,

Shrewbury, Massachusetts 01545 USA

SIR-We think it high time that someone pointed out the positive aspects of Nature's policy on sexist advertising. You do, for example, show great restraint in not accepting advertisements such as those depicting the 'Marlboro Man'. Here, a man clad only in leather and cotton, clutching a horse, smokes a cigarette. We feel that such advertisements, which display men only as virile, macho cow- boys, are sexist stereotypes that have little to do with reality. Men do not only ride horses. We rejoice that our male colleagues can read Nature every week without feeling that they have been reduced to such symbols.

Your Pharmacia advertisements (specifically, the inside cover of the 2 October 1986 issue) are to be praised. They manage to show a man and woman as hardworking, attractive, intelligent human beings. It is not even suggested that the technician knows what a horse is.

Gillian E. Wu, Susan Carson, Una Chen, Ellen Hsu, Polly Matzinger, Susan McClure, Gitta Stockinger, AKiko Takeda, Judy P. WAys Basel Institute for Immunology, Grenzacherstrasse 487, Postfach, CH-4005 Basel, Switzerland

\section{Mais plus ça change...}

SIR-In his astonishingly accurate book Anticipations (of the reaction of mechanical and scientific progress upon human life and thought) (1904), H.G. Wells predicted many of the major technical discoveries with which we are now familiar.

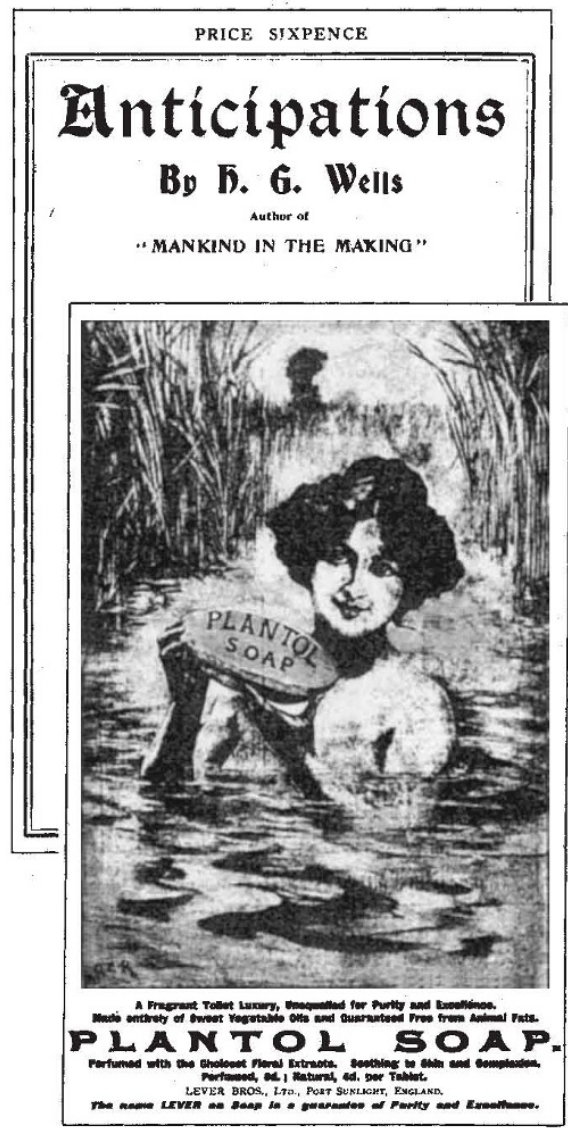

However, he also anticipated then what would later become appropriate as a back cover for a scientific publication.

A.L. MACKAY

Department of Crystallography,

Birkbeck College,

Malet Street, London WCIE 7HX, UK 